\title{
INTRATEKALINĖS CHEMOTERAPIJOS PRINCIPAI: INDIKACIJOS, MEDIKAMENTAI, PROCEDŪRA, KOMPLIKACIJOS
}

\author{
Paulius Bašinskas ${ }^{1}$, Austẻja Gerulytė ${ }^{1}$, Milda Rudžianskiené ${ }^{3}$, Andrius Macas², \\ Darius Trepenaitis ${ }^{2}$, Rolandas Gerbutavičius ${ }^{3}$, Viktoras Rudžianskas ${ }^{3}$ \\ ${ }^{1}$ Lietuvos sveikatos mokslu universiteto Medicinos akademijos Medicinos fakultetas, \\ ${ }^{2}$ Lietuvos sveikatos mokslu universiteto Medicinos akademijos Medicinos fakultetas, \\ Anesteziologijos klinika, ${ }^{3}$ Lietuvos sveikatos mokslu universiteto Medicinos akademijos \\ Medicinos fakultetas, Onkologijos ir hematologijos klinika
}

Raktažodžiai: intratekalinè chemoterapija, juosmeninè punkcija.

\begin{abstract}
Santrauka
Intratekalinè chemoterapija - chemoterapijos vaistuc suleidimas ị stuburo smegenų kanalą, siekiant išgydyti onkologinę ligą arba išvengti jos recidyvo centrinejje nervų sistemoje. Dažniausiai šiam tikslui naudojami vaistai yra metotreksatas, citarabinas ir gliukokortikoidai. Jie gali būti naudojami atskirai arba kartu, t.y. taikoma triguba intratekalinè chemoterapija. Vaistai suleidžiami ị subarachnoidinị tarpą atlikus juosmeninę punkciją. Po procedūros pacientą svarbu stebèti dèl nepageidaujamų chemoterapijos preparatų reiškinių (aseptinio meningito, cheminio arachnoidito, encefalopatijos, traukulių ir kt.) ir juosmeninès punkcijos komplikacijų (galvos ar nugaros skausmo, kraujavimo, infekcijos ir kt.).
\end{abstract}

\section{İvadas}

Pirmą sèkmingą juosmeninę punkciją 19-ojo amžiaus pabaigoje atliko Heinrich Iraneus Quincke - komoje esantis pacientas su įtariamu tuberkulioziniu meningitu išgyveno. Panašiu laiku tą pačią procedūrą 4 pacientams (vienas sirgo bakteriniu meningitu, kiti trys - tuberkulioziniu) atliko ir Walter Essex Wynter, bet visi pacientai mirè (1). Tobulejjant juosmeninès punkcijos technikai bei mažejjant komplikacijų skaičiui, èmè didèti procedūros atlikimo mastai. 1970 metais vaikams į stuburo smegenų kanalą pradèti leisti chemoterapijos vaistai ūminès limfoblastinès leukemijos recidyvo profilaktikai. Tai žymiai pagerino ligos prognozę -5 metų išgyvenamumas padidejo apie 80 proc. (2).

Chemoterapijos vaistų suleidimas ị stuburo smegenų kanalą, siekiant išgydyti onkologinę ligą arba išvengti jos recidyvo centrineje nervų sistemoje (CNS), vadinama intratekaline chemoterapija (3). Kraujo-smegenų barjeras riboja ịvairių molekulių pernašą, todèl ịprastomis dozèmis sistemiškai skiriami chemoterapijos vaistai smegenų skystyje terapinès koncentracijos nepasiekia. Sisteminès chemoterapijos dozès didinimas lemtų dažnesnius ir stipresnius nepageidaujamus reiškinius, bet to galima išvengti vaistus tiesiogiai leidžiant ị stuburo smegenų kanalą. Kraujo-smegenų barjero apejimas ir nedidelis smegenų skysčio pasiskirstymo tūris leidžia intratekalinei chemoterapijai naudoti mažas vaistų dozes, kurios užtikrina efektyvų onkologinių ligų gydymą ar profilaktiką (4).

Nors nepageidaujamų sisteminès chemoterapijos reiškinių pavyksta išvengti, vis dèlto gali atsirasti vietinių komplikacijų dèl suleisto vaisto poveikio ar pačios juosmeninės punkcijos atlikimo, pavyzdžiui, galvos skausmas, infekcija, kraujavimas ir kt. (5) Dẻl šios priežasties anesteziologams svarbu gerai išmanyti teorinius ir praktinius chemoterapijos vaistų suleidimo ị stuburo smegenų kanalą ypatumus.

Darbo tikslas - apžvelgti intratekalinės chemoterapijos indikacijas, kontraindikacijas, naudojamus medikamentus, atlikimo procedūrą, komplikacijas ir jų valdymą.

\section{Tyrimo metodika}

Atlikta mokslinių straipsnių paieška elektroninèse duomenų bazèse PubMed (Medline), ScienceDirect ir Wiley Online Library, naudojant raktinius žodžius chemotherapy AND intrathecal. Atrinkti ir išnagrineti naujausi temą atitinkantys tyrimai. Apibendrinta informacija pateikiama šiame straipsnyje.

\section{Rezultatai ir jų aptarimas}

Intratekalinès chemoterapijos indikacijos. Chemoterapijos vaistų suleidimas ị stuburo smegenų kanalą turi du 
tikslus - gydyti onkologinę ligą arba išvengti jos recidyvo CNS.

Indikacijos gydymui. Ne Hodžkino limfoma. Pirminè CNS limfoma yra retas ne Hodžkino limfomos variantas sergamumas yra 0,47 atvejų 100000 gyventojų per metus (6). Limfomos recidyvas CNS, kitaip nei pirminè CNS limfoma, yra dažnas ir priklauso nuo ne Hodžkino limfomos tipo (7). Limfoblastinès limfomos atveju piktybinès ląstelès smegenų skystyje aptinkamos 2-26 proc. sergančiujų (8); Burkitt limfomos - 13-17 proc. (9), difuzinès didelių B ląstelių limfomos -5 proc. (10), mantijos ląstelių limfomos 4,1-5,6 proc. (11,12). Limfomos recidyvo CNS rizika didejja, jeigu diagnozuojama III ar IV stadijos liga, nustatomas išplitimas retroperitoniniuose limfiniuose mazguose arba kaulu čiulpuose, sẻklidèse, krūtyje, sinusuose, ryklèje, tonzilèse, paravertebraliai, inkstuose, antinksčiuose, išmatuojama padidejjusi LDH koncentracija arba sumažèjęs albumino kiekis kraujo plazmoje (13). Pirminè limfoma ir limfomos recidyvas CNS pasireiškia ịvairiais neurologiniais simptomais ir lemia blogą ligos prognozę (14).

Üminè limfoblastinė leukemija. 5-10 proc. pacientu, sergančių ūmine limfoblastine leukemija, nustatomos navikinès ląstelès (blastai) CNS (15). Rizikos veiksniai neuroleukemijai išsivystyti yra didelis leukocitų skaičius, tarpuplaučio infiltracija ir T ląstelių imunofenotipas (16). CNS pažeidimas ūminès limfoblastinès leukemijos atveju dažniausiai būna besimptomis, bet retais atvejais gali pasireikšti galvinių nervų pažeidimu ar meningizmu (17).

Ūminè mieloidinè leukemija. Neuroleukemija ūminès mieloidinès leukemijos atveju pasireiškia retai $-0,6$ proc. sergančiujų pirmą kartą diagnozavus ligą, 2,9 proc. nustačius recidyvą (18).

Ne hematologinių vėžinių ligų metastazès CNS. Sergant krūties vėžiu piktybinès ląstelès smegenų skystyje aptinkamos 5-8 proc. atvejų, nesmulkių ląstelių plaučių karcinoma -9-25 proc., melanoma - 6-18 proc., kitų vėžinių ligų atveju - rečiau (19). Véžio invazyvumą i CNS lemia tam tikri genetiniai pokyčiai, pavyzdžiui, apie 50 proc. nesmulkių ląsteliu plaučių karcinomos atveju aptinkama endotelio augimo faktoriaus receptoriaus (EGRF) mutacija (20). CNS infiltracija pasireiškia galvos skausmu, dezorientacija, diplopija, klausos sutrikimu, radikulopatijomis, mielopatijomis, šakneliniais simptomais (21). Metastazių aptikimas CNS yra blogos prognozès ženklas - neskiriant gydymo išgyvenamumas siekia 4-6 sav., gydant - 3-6 mèn. (19). Svarbu paminèti, kad intratekalinè chemoterapija naikina nedideles pavienes smegenu skystyje aptinkamas ar ant smegenų dangalų prisitvirtinusias navikines ląsteles, bet neveikia solidinių masių, nes negali i jas įsiskverbti (7).

Indikacijos profilaktikai. Onkohematologinès ligos recidyvo CNS profilaktika turètų būti taikoma didelès rizikos ne Hodžkino limfomų (limfoblastinès, Burkitt, difuzinès didelių B ląstelių, mantijos ląstelių ir kt.) ir ūminès limfoblastinès leukemijos atveju $(8,22,23)$.

Onkohematologinès ligos recidyvas CNS ženkliai trumpina pacientų išgyvenamumą, todèl siekiant jo išvengti yra taikoma CNS profilaktika. Sistemiškai skiriama didelių dozių chemoterapija, intratekalinè chemoterapija, kraujodaros ka-

1 lentelè. CNS įtraukimo esant hematoonkologinei ligai dažnis skirtingų limfomų ir leukemijų atveju (812,15,24-26).

\begin{tabular}{|l|c|c|c|}
\hline Hematoonkologinė liga & $\begin{array}{c}\text { Navikinių ląstelių } \\
\text { nustatymas CNS } \\
\text { pirmą kartą diagno- } \\
\text { zavus ligą }\end{array}$ & $\begin{array}{c}\text { Limfomos/ leuke- } \\
\text { mijos recidyvo CNS } \\
\text { dažnis be profilak- } \\
\text { tikos }\end{array}$ & $\begin{array}{c}\text { Limfomos/ leuke- } \\
\text { mijos recidyvo CNS } \\
\text { dažnis su profilak- } \\
\text { tika }\end{array}$ \\
\hline Limfoblastinė limfoma & $2-26$ proc. & $30-50$ proc. & $1,2-3$ proc. \\
\hline Burkitt limfoma & $13-17$ proc. & $30-50$ proc. & $2-3$ proc. \\
\hline Ūminė limfoblastinė leukemija & $5-10$ proc. & $30-50$ proc. & $3-6$ proc. \\
\hline Difuzinė didelių B ląstelių limfoma & 5 proc. & $2-27$ proc. & $0-13$ proc. \\
\hline Mantijos ląstelių limfoma & $4,1-5,6$ proc. & $4-23$ proc. & $4-7,8$ proc. \\
\hline
\end{tabular}

2 lentelẻ. Intratekalinei chemoterapijai dažniausiai naudojamų vaistų savybės.

\begin{tabular}{|l|l|c|c|l|}
\hline Vaistas & Cheminė struktūra & $\begin{array}{c}\text { Dozès skai- } \\
\text { čiavimas }\end{array}$ & \multicolumn{1}{|c|}{ Dozė } & \multicolumn{1}{c|}{$\begin{array}{c}\text { Dažniausi nepageidaujami } \\
\text { reiškiniai }\end{array}$} \\
\hline Metotreksatas & $\begin{array}{l}\text { folinės rūgšties anta- } \\
\text { gonistas }\end{array}$ & pagal amžių & $10-15 \mathrm{mg}$ & $\begin{array}{l}\text { aseptinis meningitas, cheminis arach- } \\
\text { noiditas }\end{array}$ \\
\hline Citarabinas & pirimidinų analogas & pagal amžių & $30-100 \mathrm{mg}$ & $\begin{array}{l}\text { skersinė mielopatija, aseptinis me- } \\
\text { ningitas, encefalopatija, traukuliai }\end{array}$ \\
\hline Gliukokortikoidai & steroidiniai hormonai & pagal amžių & $10-40 \mathrm{mg}$ & $\begin{array}{l}\text { galvos skausmas, pykinimas, dezo- } \\
\text { rientacija, depresija, psichozė }\end{array}$ \\
\hline
\end{tabular}


mieninių ląstelių transplantacija ir CNS radioterapija ilgina pacientų išgyvenamumą. Intratekalinè chemoterapija dẻl savo efektyvumo ir retesnių šalutinių reiškinių pakeite CNS radioterapiją recidyvo profilaktikos tikslu (8). Kartu su sistemine chemoterapija pradejus skirti monokloninị antikūnị rituksimabą, $5-6$ proc. sumažejo hematoonkologinès ligos CNS recidyvo dažnis, tačiau esant didelès rizikos limfomai recidyvų dažnis išlieka didelis (1 lentelè) (24). Recidyvo rizika didejja, jeigu onkologinis procesas išplinta ị retroperitoninius limfmazgius, daugiau nei vieną ekstranodalinị organą (ypač sėklides, akiduobę ar kaulų čiulpus), nustatoma padidejusi LDH koncentracija arba sumažejęs albumino kiekis kraujo plazmoje, paciento amžius < $60 \mathrm{~m}$. (13).

Intratekalinės chemoterapijos kontraindikacijos. Pacientui kontraindikuotina atlikti juosmeninę punkciją, jeigu nustatomas padidejęs intrakranijinis spaudimas, sepsis, infekcija punkcijos vietoje, alergija skiriamiems vaistams, trombocitu skaičius $<50 \times 10^{9} / 1$ (pagal Amerikos regioninès anestezijos draugijos gaires trombocitų skaičius $<75 \times 10^{9} / 1$ ), sutrikęs kraujo krešèjimas arba antikoaguliantų vartojimas $(27,28)$.

Intratekalinei chemoterapijai naudojami vaistai. Dažniausiai naudojami vaistai yra metotreksatas, citarabinas ir gliukokortikoidai (2 lentelè). Jie gali būti naudojami atskirai arba kartu - triguba intratekalinè chemoterapija (2).

Metotreksatas yra folinès rūgšties antagonistas, kuris inhibuodamas dihidrofolatų reduktazę stabdo purinų ir DNR sintezę (19). Smegenų skystyje metotreksato pusinis skilimo periodas yra bifazis 4,5 val. ir 14 val., todèl vaisto koncentracija nukrenta žemiau terapinès per 4 dienas (21). Vaisto dozė yra 10-15 mg - ji apskaičiuojama pagal amžių, bet ne pagal kūno paviršiaus plotą ar svorị (2). Smegenų skystyje metotreksatas geriau veikia hematologines ar krūties véžio ląsteles nei nesmulkių ląstelių plaučių karcinomą (21). Dažniausi nepageidaujami intratekaliai naudojamo metotreksato reiškiniai yra aseptinis meningitas ir cheminis arachnoiditas, kuriam būdingas galvos skausmas, karščiavimas, pykinimas, vèmimas, sprando raumenų rigidiškumas ir pleocitozė smegenų skystyje. Jie pasireiškia apie 10 proc. pacientų. Rečiau stebimas galvos svaigimas, galūnių silpnumas, regos sutrikimai, traukuliai, poūmè encefalopatija ar leukoencefalopatija, kuri gali pasireikšti praejjus mènesiams ar metams po vaisto suleidimo. Nepageidaujamų reiškinių riziką sumažina kartu skiriami gliukokortikoidai (2).

Citarabinas yra pirimidinų analogas, kuris inhibuoja DNR sintezę (19). Intraveniškai skiriamo citarabino pusinis eliminacijos laikas trumpas (mažiau nei 20 min.), nes ji skaido kepenų citidino deaminazé, intratekaliai - ilgesnis (2-6 val.), nes smegenų skystyje nèra ji skaidančių fermentų. Terapinė vaisto koncentracija išsilaiko iki 24 val. (4). Vaisto dozė yra
30-100 mg - ji apskaičiuojama pagal amžių. Nepageidaujami citarabino reiškiniai yra reti - skersinè mielopatija, aseptinis meningitas, encefalopatija ir traukuliai. Nepageidaujamų reiškinių riziką sumažina kartu skiriami gliukokortikoidai (2).

Norint pailginti citarabino veikimą smegenų skystyje, buvo sukurtas liposominis citarabinas. Jo pusinis eliminacijos laikas yra 100-263 val., terapinè vaisto koncentracija smegenu skystyje išsilaiko iki 28 d. (2). Liposominio citarabino dozė yra $50 \mathrm{mg}$ (19). Nepageidaujami reiškiniai vartojant liposominį citarabinị pasireiškia dažniau nei ịprastą citarabiną, ypač kartu vartojant dideles intravenines metotreksato ir citarabino dozes. Dažniausiai stebimas aseptinis encefalitas, traukuliai, regimojo nervo disko edema ir cauda equina sindromas (15).

Gliukokortikoidai yra steroidiniai hormonai, kurie intratekaliai vartojami kartu su metotreksatu ir citarabinu, kad sumažintų nepageidaujamų reiškinių dažnį, ypač cheminio arachnoidito, ir didintų chemoterapijos preparatų efektyvumą (4). Vaisto dozè yra 10-40 mg - ji apskaičiuojama pagal amžių. Intratekaliai leidžiant gliukokortikoidus gali išsivystyti galvos skausmas, pykinimas, dezorientacija, depresija ar psichozè, bet šie nepageidaujami reiškiniai yra reti (2).

Triguba intratekalinė chemoterapija. I̦ stuburo smegenų kanalą kartu leidžiant metotreksatą, citarabiną ir gliukokortikoidus tikimasi jų sinergistinio poveikio ir retesnių nepageidaujamų reiškinių (29). Triguba intratekalinè chemoterapija yra veiksmingesnè onkologinèms ligoms gydyti ir recidyvo profilaktikai CNS nei atskirai skiriamas metotreksatas ar citarabinas (25). Nepageidaujamų reiškinių dažnis mažas dèl kartu vartojamų gliukokortikoidų, tačiau kartais stebimas galvos skausmas, pykinimas, vėmimas ir karščiavimas (30).

Kiti vaistai. Intratekalinei chemoterapijai taip pat gali būti naudojami monokloniniai antikūnai (rituksimabas, transtuzumabas), thiotepa ir kt. (2)

Verta prisiminti, kad vinca alkaloidai (vinkristinas, vinblastinas, vindesinas ir kt.) bei proteosomų inhibitoriai intratekalinei chemoterapijai nenaudojami dèl neurotoksinio poveikio (31).

Chemoterapijos medikamentų sušvirkštimas. Prieš procedūrą gydytojas atlieka higieninį rankų paruošimą. Pacientas guldomas paprastai ant kairiojo šono (ant dešiniojo, jeigu gydytojas kairiarankis), galva ir kojos yra prilenkiamos prie krūtinès (27). Brèžiama menamoji linija, jungianti dubenkaulių klubines skiauteres, kuri ịprastai kerta stuburą taške, atitinkantị tarpą tarp L3 ir L4 slankstelių keterinių ataugų. Dažniausiai punkcija atliekama L3-L4, bet galima ir L4-L5 ar L2-L3 tarpuose. Išrinkta punkcijos vieta pažymima. Gydytojas pasikeičia pirštines i i sterilias, prieš tai atlikdamas antiseptinį rankų paruošimą. Atliekamas punkcijos vietos 
antiseptinis paruošimas. Vèliau ị odą ir poodị sušvirkščiama vietinio anestetiko, pavyzdžiui, 2 proc. lidokaino. Punkcijai rekomenduojama naudoti $22 \mathrm{G}$ pieštukines (pencil - point) adatas, kurios mažina popunkcinių galvos skausmų tikimybę. Kai kuriuose centruose įprasta naudoti Quincke tipo adatas. Adata yra praduriama oda, poodis, supraspinalinis ir interspinalinis raištis, geltonasis raištis, kietasis dangalas ir voratinklinis dangalas (5).

Patekus į subarachnoidinị tarpą pirma yra paimamas smegenų skystis ištyrimui. Pašalinama dalis smegenų skysčio - apie 5-15 ml. Vaistai švirkščiami paeiliui su 1-2 min. intervalu - pirmas sušvirkščiamas metotreksatas, antras citarabinas, trečias - pasirinktas gliukokortikoidas (2).

Paciento stebẻjimas po procedūros. Po intratekalinio chemopreparato sušvirkštimo pacientas turi likti gulimoje padètyje 30-60 min. Kai kurie autoriai gulimą režimą rekomenduoja tęsti iki 12 val. (2,32). Po juosmeninès punkcijos patariama vartoti daugiau skysčių. Svarbu stebèti pacientą dèl galvos skausmo, kojų silpnumo, pykinimo, vėmimo, karščiavimo, lokalių reakcijų, traukulių, sąmonės sutrikimo ir kt. (5).

Juosmeninės punkcijos komplikacijos. Galvos skausmas yra viena dažniausių juosmeninès punkcijos komplikacijų, kurią patiria iki 11 proc. pacientų (33). Jis lokalizuojasi kaktoje arba pakaušyje ir gali trukti iki 2 sav. Skausmą sukelia smegenų skysčio tekèjimas per kietaji smegenų dangalą ir skausmui jautrių smegenų struktūrų tempimas, todèl skausmas intensyvejja vertikalioje pozicijoje, mažeja - horizontalioje. Rizikos veiksniai skausmui po juosmeninès punkcijos išsivystyti yra moteriška lytis, amžius tarp 31 ir $50 \mathrm{~m}$., anksčiau patirtas skausmas po juosmeninès punkcijos ir stuburui statmena nuožulnaus adatos galo pozicija (34).

Kraujavimas yra retas pacientams, kurie nevartoja antikoaguliantų ir kurių krešèjimo sistema nesutrikusi. Deja, hematoonkologinès ligos ar jų gydymas chemoterapijos vaistais gali lemti mielosupresiją ir didinti kraujavimo tikimybę. Riziką taip pat didina komplikuota juosmeninès punkcijos procedūra, kurios nepavyko atlikti iš pirmo karto. Svarbu prisiminti, kad nerekomenduojama atlikti juosmeninès punkcijos, jeigu paciento trombocitų skaičius $<50 \times 10^{\%} / 1$ (pagal Amerikos regioninès anestezijos draugijos gaires $<75 \mathrm{x}$ $\left.10^{9} / 1\right)$, o INR $<1,4(35)$.

Nugaros skausmu po juosmeninès punkcijos skundžiasi trečdalis pacientų. Jis dažniausiai tęsiasi kelias dienas ir praeina savaime (33).

Infekcija po juosmeninès punkcijos yra reta komplikacija, nes procedūros metu yra laikomasi griežtų antiseptikos taisyklių (36).

Labai sunkios juosmeninès punkcijos komplikacijos (smegenų edema ir strigimas, traukuliai, koma) pasitaiko retai, tačiau reikalauja skubios diagnostikos ir gydymo (36).

\section{Išvados}

Intratekalinè chemoterapija yra efektyvus onkologiniu ligu gydymo ir onkologinès ligos recidyvo CNS metodas, dažniausiai naudojamas ūmių leukemijų ir didelès rizikos ne Hodžkino limfomos atveju. Triguba intratekalinè chemoterapija yra veiksmingesnè ir saugesnè nei atskirai vartojamas metotreksatas ar citarabinas. Po juosmeninès punkcijos atlikimo ir chemoterapijos preparatų suleidimo i subarachnoidinị tarpą svarbu stebèti pacientą dèl galvos skausmo, kojų silpnumo, pykinimo, vėmimo, karščiavimo ir kt. Pasireiškus sunkioms komplikacijoms (smegenų edemai ir strigimui, traukuliams, komai) svarbu skubi diagnostika ir atitinkamas gydymas.

\section{Literatūra}

1. Pearce JM. Walter essex wynter, quincke, and lumbar puncture. J Neurol Neurosurg Psychiatry 1994;57(2):179.

https://doi.org/10.1136/jnnp.57.2.179

2. Olmos-Jiménez R, Espuny-Miró A, Cárceles-Rodríguez C, Díaz-Carrasco MS. Practical aspects of the use of intrathecal chemotherapy. Farm Hosp 2017;41(1):105-29.

3. Lee YC, Hsieh CC, Chuang JP, Li CY. The necessity of intrathecal chemotherapy for the treatment of breast cancer patients with leptomeningeal metastasis: a systematic review and pooled analysis. Curr Probl Cancer 2017;41(5):355-70.

https://doi.org/10.1016/j.currproblcancer.2017.07.001

4. Kwong YL, Yeung DYM, Chan JCW. Intrathecal chemotherapy for hematologic malignancies: drugs and toxicities. Ann Hematol 2009;88(3):193-201.

https://doi.org/10.1007/s00277-008-0645-y

5. Doherty CM, Forbes RB. Diagnostic lumbar puncture. Ulster Med J 2014;83(2):93-102.

6. Villano JL, Koshy M, Shaikh H, Dolecek TA, McCarthy BJ. Age, gender, and racial differences in incidence and survival in primary CNS lymphoma. Br J Cancer 2011;105(9):1414-8. https://doi.org/10.1038/bjc.2011.357

7. Dara A, Mook BB, Doorduijn JK, van den Bent MJ, Dinmohamed AG, Bromberg JEC. Efficacy of intrathecal chemotherapy in patients with central nervous system involvement of hematological malignancies: a retrospective analysis. J Neurooncol 2018;139(1):117-23.

https://doi.org/10.1007/s11060-018-2849-x

8. Bassan R, Maino E, Cortelazzo S. Lymphoblastic lymphoma: an updated review on biology, diagnosis, and treatment. Eur J Haematol 2016;96(5):447-60.

https://doi.org/10.1111/ejh.12722

9. Jiang M, Zhu J, Guan YS, Zou LQ. Primary central nervous system Burkitt lymphoma with non-immunoglobulin heavy chain translocation in right ventricle: case report. Pediatr Hematol Oncol 2011;28(5):454-8.

https://doi.org/10.3109/08880018.2011.566599 
10. Pe-alver FJ, Sancho JM, de la Fuente A, Olave MT, Martín A, Panizo C, Pérez E, Salar A, Orfao A. Guidelines for diagnosis, prevention and management of central nervous system involvement in diffuse large B-cell lymphoma patients by the Spanish Lymphoma Group (GELTAMO). Haematologica 2017;102(2):235-45 https://doi.org/10.3324/haematol.2016.149120

11. González-Bonet LG, García-Boyero R, Gaona-Morales J. Mantle cell lymphoma with central nervous system involvement simulating bilateral subdural hematomas. World Neurosurg 2017;99:808-808.

https://doi.org/10.1016/j.wneu.2016.12.122

12. Chihara D, Asano N, Ohmachi K, Nishikori M, Okamoto M, Sawa M, Sakai R, Okoshi Y, Tsukamoto N, Yakushijin Y, Nakamura S, Kinoshita T, Ogura M, Suzuki R. Ki-67 is a strong predictor of central nervous system relapse in patients with mantle cell lymphoma (MCL). Ann Oncol 2015;26(5):966-73. https://doi.org/10.1093/annonc/mdv074

13. Lim HY, Thiel E, Glantz MJ. To protect and defend: central nervous system prophylaxis in patients with non-Hodgkin's lymphoma. Curr Opin Oncol 2008;20(5):495-501.

https://doi.org/10.1097/CCO.0b013e32830b829e

14. Qian L, Zhou C, Shen J, Cen J, Yin W. Treatment of newly diagnosed B-cell origin primary CNS lymphoma with systemic R-IDARAM chemotherapy and intrathecal immunochemotherapy. Oncotarget 2016;7(18):25783-90.

https://doi.org/10.18632/oncotarget. 8370

15. Larson RA. Managing CNS disease in adults with acute lymphoblastic leukemia. Leuk Lymphoma 2018;59(1):3-13.

https://doi.org/10.1080/10428194.2017.1326597

16. Alsadeq A, Schewe DM. Acute lymphoblastic leukemia of the central nervous system: on the role of PBX1. Haematologica 2017;102(4):611-3.

https://doi.org/10.3324/haematol.2017.165142

17. Terwilliger T, Abdul-Hay M. Acute lymphoblastic leukemia: a comprehensive review and 2017 update. Blood Cancer J 2017;7(6):577.

https://doi.org/10.1038/bcj.2017.53

18. Alakel N, Stölzel F, Mohr B, Kramer M, Oelschlägel U, Röllig C, Bornhäuser M, Ehninger G, Schaich M. Symptomatic central nervous system involvement in adult patients with acute myeloid leukemia. Cancer Manag Res 2017;9:97-102. https://doi.org/10.2147/CMAR.S125259

19. Mack F, Baumert BG, Schäfer N, Hattingen E, Scheffler B, Herrlinger U, Glas M. Therapy of leptomeningeal metastasis in solid tumors. Cancer Treat Rev 2016;43:83-91.

https://doi.org/10.1016/j.ctrv.2015.12.004

20. Wang Y, Liu S, Wei X, Yan B, Li J, Su Z, Liu A, Zhang Y. Non-small cell lung cancer leptomeningeal metastases treated with intrathecal therapy plus osimertinib and temozolomide and whole-brain radiation therapy: a case report. Onco Targets Ther 2018;11:4733-8.
https://doi.org/10.2147/OTT.S164968

21. Beauchesne P. Intrathecal chemotherapy for treatment of leptomeningeal dissemination of metastatic tumours. Lancet Oncol 2010;11(9):871-9. https://doi.org/10.1016/S1470-2045(10)70034-6

22. Hall KH, Valla K, Flowers CR, Cohen JB. Intrathecal central nervous system prophylaxis in patients with diffuse large b-cell lymphoma at an academic healthcare system. Clinical Lymphoma, Myeloma and Leukemia 2018;89-94.

23. Paul S, Kantarjian H, Jabbour EJ. Adult acute lymphoblastic leukemia. Mayo Clin Proc 2016;91(11):1645-66.

https://doi.org/10.1016/j.mayocp.2016.09.010

24. Gleeson M, Counsell N, Cunningham D, Chadwick N, Lawrie A, Hawkes EA, McMillan A, Ardeshna KM, Jack A, Smith P, Mouncey P, Pocock C, Radford JA, Davies J, Turner D, Kruger A, Johnson P, Gambell J, Linch D. Central nervous system relapse of diffuse large B-cell lymphoma in the rituximab era: results of the UK NCRI R-CHOP-14 versus 21 trial. Ann Oncol 2017;28(10):2511-6.

https://doi.org/10.1093/annonc/mdx353

25. Pui $\mathrm{CH}$, Thiel E. Central nervous system disease in hematologic malignancies: historical perspective and practical applications. Semin Oncol 2009;36:2-16.

https://doi.org/10.1053/j.seminoncol.2009.05.002

26. Conconi A, Franceschetti S, Lobetti-Bodoni C, Stathis A, Margiotta-Casaluci G, Ramponi A, Mazzucchelli L, Bertoni F, Ghielmini M, Gaidano G, Cavalli F, Zucca E. Risk factors of central nervous system relapse in mantle cell lymphoma. Leuk Lymphoma 2013;54(9):1908-14.

https://doi.org/10.3109/10428194.2013.767454

27. Perry S, Barnes J, Allan A. Performing and interpreting a lumbar puncture. Br J Hosp Med 2018;79(12):183-7.

https://doi.org/10.12968/hmed.2018.79.12.C183

28. Narouze S, Benzon HT, Provenzano D, Buvanendran A, De Andres J, Deer T, Rauck R, Huntoon MA. Interventional spine and pain procedures in patients on antiplatelet and anticoagulant medications (second edition): guidelines from the American Society of Regional Anesthesia and Pain Medicine, the European Society of Regional Anaesthesia and Pain Thera. Reg Anesth Pain Med 2018;43(3):225-62.

29. Shapiro WR, Johanson CE, Boogerd W. Treatment modalities for leptomeningeal metastases. Semin Oncol 2009; 36:46-54. https://doi.org/10.1053/j.seminoncol.2009.05.006

30. Olmos-Jiménez R, Díaz-Carrasco MS, Caba-as-Perianes V, Valderrey-Pulido M, Espuny-Miró A. Evaluation of standardized triple intrathecal therapy toxicity in oncohematological adult patients. Farm Hosp 2017;41(5):611-7.

31. Liu H, Tariq R, Liu GL, Yan H, Kaye AD. Inadvertent intrathecal injections and best practice management. Acta Anaesthesiol Scand 2017;61(1):11-22.

https://doi.org/10.1111/aas.12821

32. Li J, Li X, Tong X, Liu J, Huang B, Chen M, Kuang L, Zhou Z, 
$\mathrm{Xu}$ D. Investigation of the optimal duration of bed rest in the supine position to reduce complications after lumbar puncture combined with intrathecal chemotherapy: a multicenter prospective randomized controlled trial. Support Care Cancer 2018;26(9):2995-3002.

https://doi.org/10.1007/s00520-018-4142-0

33. Nath S, Koziarz A, Badhiwala JH, Alhazzani W, Jaeschke R, Sharma S, Banfield L, Shoamanesh A, Singh S, Nassiri F, Oczkowski W, Belley-Côté E, Truant R, Reddy K, Meade MO, Farrokhyar F, Bala MM, Alshamsi F, Krag M, et al. Atraumatic versus conventional lumbar puncture needles: a systematic review and metaanalysis. Lancet 2018;391(10126):1197-204. https://doi.org/10.1016/S0140-6736(17)32451-0

34. (IHS) HCC of the IHS. Headache Classification Committee of the International Headache Society (IHS) The International Classification of Headache Disorders, 3rd edition. Cephalalgia 2018;38(1):1-211. https://doi.org/10.1177/0333102417738202

35. Sawaya C, Sawaya R. Central nervous system bleeding after a lumbar puncture: still an ongoing complication. Am J Case Rep 2018;19:1103-7. https://doi.org/10.12659/AJCR.910912

36. Pitkänen MT, Aromaa U, Cozanitis DA, Förster JG. Serious complications associated with spinal and epidural anaesthesia in Finland from 2000 to 2009. Acta Anaesthesiol Scand 2013;57(5):553-64.

https://doi.org/10.1111/aas.12064

\section{THE PRINCIPLES OF INTRATHECAL CHEMOTHERAPY: INDICATIONS, DRUGS, PROCEDURE, COMPLICATIONS \\ P.Bašinskas, A.Gerulytė, M.Rudžianskienė, A.Macas, D.Trepenaitis, R.Gerbutavičius, V.Rudžianskas}

Key words: intrathecal chemotherapy, lumbar puncture.

Summary

Intrathecal chemotherapy is the injection of chemotherapeutic drugs into the subarachnoid space in order to treat an oncologic disease or avoid its relapse in the central nervous system. The most commonly used drugs are methotrexate, cytarabine and glucocorticoids. They can be used separately or in a combination, in the called triple intrathecal chemotherapy. Drugs are administered into the subarachnoid space via a lumbar puncture. It's important to monitor the patient for adverse effects of injected drugs (aseptic meningitis, chemical arachnoiditis, etc.) and complications of the lumbar puncture (headache, lumbar pain, bleeding, infection, etc.).

Correspondence to: paulius.basinsk@gmail.com

Gauta 2019-03-22 